UDC 614.44

DOI: 10.21668/health.risk/2017.1.01.eng

\title{
RISK-ORIENTED APPROACH APPLICATION AT PLANNING AND ORGINIZING ANTIEPIDEMIC PROVISION OF MASS EVENTS
}

\author{
D.V. Efremenko ${ }^{1}$, I.V. Kuznetsova ${ }^{1}$, V.G. Orobey $^{2}$, A.A. Efremenko ${ }^{3}$, V.M. Dubyanskiy ${ }^{1}$, \\ E.A. Manin ${ }^{1}$, D.A. Prislegina ${ }^{1}$, O.V. Semenko ${ }^{1}$ \\ ${ }^{1}$ Stavropol Plague Control Research Institute, 13-15 Sovetskaya Str., Stavropol, 355035, Russian Federation \\ ${ }^{2}$ Territory Administration of the Federal Supervision Service for Consumer's Rights Protection and Human Welfare \\ in the Krasnodar Region at c.-r. Sochi, 27 Rose Str., Sochi, 354000, Russian Federation \\ ${ }^{3}$ Stavropol State Medical University, 310 Mira Str., Stavropol, 355017, Russian Federation
}

Mass events tend to become more and more dangerous for population health, as they cause various health risks, including infectious pathologies risks. Our research goal was to work out scientifically grounded approaches to assessing and managing epidemiologic risks as well as analyze their application practices implemented during preparation to the Olympics-2014, the Games themselves, as well as other mass events which took place in 20142016. We assessed epidemiologic complications risks with the use of diagnostic test-systems and applying a new technique which allowed for mass events peculiarities. The technique is based on infections ranking as per 3 potential danger categories in accordance with created criteria which represented quantitative and qualitative predictive parameters (predictors). Application of risk-oriented approach and multi-factor analysis allowed us to detect exact possible maximum requirements for providing sanitary-epidemiologic welfare in terms of each separate nosologic form. As we enhanced our laboratory base with test-systems to provide specific indication as per accomplished calculations, it enabled us, on one hand, to secure the required preparations, and, on the other hand, to avoid unnecessary expenditures. To facilitate decision-making process during the Olympics-2014 we used an innovative product, namely, a computer program based on geoinformation system (GIS). It helped us to simplify and to accelerate information exchange within the frameworks of intra- and interdepartmental interaction. "Dynamic epidemiologic threshold" was daily calculated for measles, chickenpox, acute enteric infections and acute respiratory viral infections of various etiology. And if it was exceeded or possibility of "epidemiologic spot" for one or several nosologies occurred, an automatic warning appeared in GIS.

Planning prevention activities regarding feral herd infections and zoogenous extremely dangerous infections which were endemic for Sochi was accomplished taking the completed assessment into account.

(C) Efremenko D.V., Kuznetsova I.V., Orobey V.G., Efremenko A.A., Dubyanskiy V.M., Manin E.A., Prislegina D.A., Semenko O.V., 2017

Dmitriy V. Efremenko - candidate of medical sciences, leading researcher at epidemiology laboratory (e-mail: efremenko26@mail.ru; tel.: +7 (962) 459-07-47). 03-12).

Irina V. Kuznetsova - researcher at biochemical laboratory (e-mail: snipchi@ mail.stv.ru; tel.: +7 (8652) 26-

Vladimir G. Orobey - candidate of medical sciences, head of territorial department (e-mail: sochi@ kubanrpn.ru; tel.: +7 (8622) 64-79-48).

Anna A. Efremenko - candidate of medical sciences, assistant at common and biological chemistry department (e-mail: ania300380@ mail.ru; tel.: +7 (8652) 35-61-85).

Vladimir M. Dubyanskiy - Doctor of Biological Sciences, Head of Epizootologic monitoring and prediction department (e-mail: snipchi@ mail.stv.ru; tel.: +7 (8652) 26-03-12).

Evgeniy A. Manin - candidate of medical sciences, senior researcher at epidemiology laboratory (e-mail: snipchi@mail.stv.ru; tel.: +7 (8652) 26-03-12).

Daria A. Prislegina - junior researcher at epidemiology laboratory (e-mail: snipchi@ mail.stv.ru; tel.: +7 (8652) 26-03-12).

Oksana V. Semenko - analyst (geo-information specialist) at epidemiology laboratory (e-mail: snipchi@mail.stv.ru; tel.: +7 (8652) 26-03-12). 
The positive experience obtained through risk-oriented organization of certain activities aimed at providing anti-epidemic safety of mass international events on the Russian Federation territory allows us to be optimistic about prospects of wider implementation of the approach described above and other similar approaches based on health risk analysis principles.

Key words: epidemiologic risks, risk-oriented approach, mass events, infectious diseases, epidemiologic surveillance, risk assessment, risk management, geoinformation system.

Implementation of risk-oriented models into practical activities performed by surveillance authorities is a modern trend. Application of such models helps to optimize expenditures, and to make well-ground distributions of labor resources choosing most vital tasks [3,9].

This effect has cascade nature as motivation preconditions for improving surveillance subjects' activities are created.First of all, various processes, manufactured products, and provided services become safer and it leads to lower risks related to them; consequently, a number of necessary surveillance activities also goes down.

There are changes in the sphere of providing sanitary-epidemiologic welfare of the population as hygienic standardization concepts are being gradually replaced by health risk analysis concepts which are better in line with contemporary social and economic conditions [3]. We should point out that nowadays issues related to assessing risks caused by impacts of chemical and physical environmental factors are studied more profoundly in comparison with biological factors impacts. To control such factors, one usually uses techniques mostly adapted for sanitary microbiology tasks. It is next to impossible to fully solve tasks on predicting epidemiologic situations in relation to a wide range of infectious diseases with the use of such techniques; so, it is also impossible to create sufficient scientific grounds for risk management.

Expert multi-score risk assessment technique is the most widely spread one in everyday activities of epidemiologic surveillance. In some cases qualitative determination of risks level is accomplished without any clear criteria and is based only on experience a correspondent specialist has and only on the results of studying up-to-date information which is available to this specialist. But still a man even having maximum possible competence in his or her sphere of activity makes only subjective assessments and it can greatly influence data interpretation and, consequently, prediction results. In spite of the fact that qualitative techniques in most cases enabled timely identification of arising dangers, it is necessary to create new technologies of epidemiologic risks assessment which will help to reduce or even eliminate a subjective component.

Mass events involve greater and greater dangers for population health including those caused by infectious pathologies $[2,7,12$, 13]. Here epidemiologic risks level depends on a scale, duration, and season during which a mass event takes place, as well as geographic regions its participants and guests come from $[14,15]$. Additional workloads on social infrastructure and increased number of contacts between people create favorable conditions for activation of infectious agents transmissions; such infectious agents can be both endemic and brought from other territories [11]. Sporadic cases and group infective episodes are considered from the point of view of potential danger which they represent for a mass event as a whole or its separate stages. All the above-stated makes it necessary to organize specific activities aimed at danger prevention and reacting in case any unfavorable situations occur. It is advisable to introduce a new concept allowing for all peculiarities which mass events have; this new concept is mass events epidemiology. Key significance here is assigned to population health risk analysis.

Our research goal was to create scientifically grounded approaches to 
assessing and managing epidemiologic risks during mass events, and to analyze experience of their practical implementation during preparation to the Olympics-2014 and the Games themselves, as well as during other mass events which took place in Sochi in 2014-2016.

Data and methods. Our work is based on reports issued by "Stavropol Scientific Research Antiplague Institute" of Rospotrebnadzor and Rospotrebnadzor Regional office in Krasnodar Kray; these reports were dedicated to the results of these establishments' activities during mass events which took place in Sochi in 2014-2016 (The Olympics-2014, Formula-1 Gran Prix, Russia - ASEAN summit etc.).

Risk assessment in relation to various infectious diseases was accomplished in order to determine a set of activities needed for risks lowering, and for justifying volumes of providing Rispotrebnadzor specialized antiepidemic team (SAET) with diagnostic preparations. Experts used a new technique based on ranking nosologies as per three potential danger categories according to developed criteria representing qualitative and quantitative predictive parameters (predictors).

The technique is created allowing for mass events peculiarities and is first of all designed for making short-term forecasts. It involves determining whether there are epidemiologic risks predictors: yes (they exist) means 1 point, no (they are absent) means 0 points. To determine risk parameter for each separate nosologic form we should divide the obtained sum of points by a number of predictors, so that to calculate arithmetic mean for a sum of points. Risks levels were labeled as high (0.68-1.0), average (0.34-0.67), and low (0-0.33) according to a three-level assessment system.

Results and discussion. XXII Olympics and XI Paralympics Winter Games-2014 in Sochi were the greatest and the most significant sport mass event which took place on the territory of the Russian Federation in XXI century. From epidemiologic point of view, their peculiarities were the total duration of the event, which was longer than incubation period of most nosologic forms, as well as a great number of people, sportsmen, team members, maintenance personnel, and fans, being in the limited space; some of those people arrived from regions which were endemic in terms of extremely dangerous infections exotic for Russia.

There was a lot of analytical work accomplished prior to the Olympics; its results enabled determining that feral hers infections and zoogenous infections of bacterial and viral etiology registered in Krasnodar Kray represented a real danger. These infections agents belong to the 2nd pathogenicity group. Such infections occurrence was caused by a number of factors: 1) all land transport routes went through the Kray territory (motorways and railways); 2) airports in Krasnodar, Gelendzhik and Anapa received guests of the event and could be used as reserved ones; 3) a big share of fans and maintenance personnel were permanents residents of Krasnodar Kray, and this maintenance personnel included those who worked on sports objects, volunteers, and other people who had direct contacts with participants and guests of the event in their everyday activity; 4) a significant number of food stuffs suppliers certified by Sochi-2014 Organization Committee was also located on the Kray territory. Therefore, a possible carrying of infections and their agents from Krasnodar Kray was a considerable danger for sanitaryepidemiologic welfare of local population, participants and fans. Risk-oriented model was applied for epidemiologic surveillance over feral herd infections and zoogenous extremely dangerous infections on this territory.

"Internal" risk for epidemic complications occurrence during the Olympics-2014 and other mass events later on organized in Sochi was assessed in relation to hemorrhagic fever with renal syndrome (HFRS), West Nile fever (WNF), Crimean hemorrhagic fever (CHF), tularemia, 
brucellosis, and anthrax (table) [8]. To do parameters $(7$ were general and 3 were this, a list of 10 questions was made on the specific for feral herd infections and basis of studying retrospect and live data; the zoogenous infections). questions comprised predictive risk

Assessment of risk for epidemic complications occurrence in terms of feral herd infections and zoogenous extremely dangerous infections in Krasmodar Kray during a mass event (on the example of the Olympics-2014)

\begin{tabular}{|c|c|c|c|c|c|c|c|}
\hline \multirow[b]{2}{*}{ No. } & \multirow[b]{2}{*}{ Predictors (questions) } & \multicolumn{6}{|c|}{$\begin{array}{l}\text { Predictor occurrence (points) } \\
\text { (yes is } 1 \text {; no is } 0 \text { ) }\end{array}$} \\
\hline & & 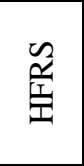 & $\sum_{3}^{L}$ & 㐊 & $\frac{\pi}{\stackrel{0}{\overparen{D}}}$ & $\frac{n}{\stackrel{n}{0}}$ & 胥 \\
\hline 1 & $\begin{array}{l}\text { Have any disease cases been registered on Krasnodar Kray territory over } \\
\text { the last } 5 \text { years? }\end{array}$ & 1 & 1 & 0 & 1 & 0 & 1 \\
\hline 2 & Have any disease cases been registered in Sochi over the last 5 years? & 1 & 0 & 0 & 0 & 0 & 0 \\
\hline 3 & $\begin{array}{l}\text { Have any disease cases been registered on Krasnodar Kray territory in a } \\
\text { season of a mass event over the last } 5 \text { years? }\end{array}$ & 1 & 0 & 0 & 0 & 0 & 0 \\
\hline 4 & $\begin{array}{l}\mathrm{IV}^{*} \text { over the last } 5 \text { years is authentically }>\text { than IV over the last } 20 \text { years (for } \\
\text { WNF and anthrax: IV over the last year is authentically }>\text { than IV over the } \\
\text { last } 5 \text { years) }\end{array}$ & 0 & 0 & 0 & 0 & 0 & 0 \\
\hline 5 & $\begin{array}{l}\text { IV in a season of a mass event over the last } 5 \text { years is authentically }>\text { than IV } \\
\text { over the last } 5 \text { years }\end{array}$ & 0 & 0 & 0 & 0 & 0 & 0 \\
\hline 6 & IV over the last 5 years is authentically $\geq 0,1$ & 1 & 0 & 0 & 0 & 0 & 0 \\
\hline 7 & $\begin{array}{l}\text { Are epidemic and epizootic infection onsets characteristic for Krasnodar } \\
\text { Kray territory during a season of a mass event? }\end{array}$ & 1 & 0 & 0 & 0 & 0 & 0 \\
\hline \multirow[t]{2}{*}{8} & $\begin{array}{l}\text { Has an infectious agent been detected (DNA, antigens, or antibodies to it } \\
\text { been detected) during examinations of field materials taken on Krasnodar } \\
\text { Kray territory over the last } 5 \text { years** }\end{array}$ & 1 & 1 & 1 & 1 & & \\
\hline & $\begin{array}{l}\text { Have epizooties been registered on Krasnodar Kray territory over the last } 5 \\
\text { years*** }\end{array}$ & & & & & 1 & 1 \\
\hline \multirow[b]{2}{*}{9} & $\begin{array}{l}\text { Has a number of infectious agent carriers on Krasnodar Kary territory over } \\
\text { the last year been authentically higher than average multi-year number?** }\end{array}$ & 0 & 0 & 0 & 0 & & \\
\hline & $\begin{array}{l}\text { Were there any adverse territories in terms of infection 1-3 months prior to a } \\
\text { mass event in Krasnodar region? (adverse territories and anthrax burials in } \\
\text { case of anthrax) } * * *\end{array}$ & & & & & 1 & 1 \\
\hline \multirow{2}{*}{10} & $\begin{array}{l}\text { Has the infection value for infectious agent carriers on Krasnodar Kray territory } \\
\text { over the last year been authentically higher than average multi-year value?** }\end{array}$ & 0 & 0 & 0 & 0 & & \\
\hline & $\begin{array}{l}\text { Is any reinforced surveillance and limits on a number of food stuffs suppliers } \\
\text { absent during a mass event?*** }\end{array}$ & & & & & 0 & 0 \\
\hline \multicolumn{2}{|r|}{ Total points sum / risk parameter } & $6 / 0,6$ & $\begin{array}{c}2 / \\
0,2\end{array}$ & $\begin{array}{c}1 / \\
0,1\end{array}$ & $\begin{array}{c}2 / \\
0,2\end{array}$ & $\begin{array}{c}2 / \\
0,2\end{array}$ & $\begin{array}{c}3 / \\
0,3\end{array}$ \\
\hline
\end{tabular}

Note: * denotes intensive value (IV) over 100,000 people;

** denotes questions only for feral herds infections;

*** denotes questions for extremely dangerous zoogenous infections

Calculated "internal" risk parameter for WNF, CHF, tularemia, brucellosis, and anthrax, was low, but it was average for HFRS.

Overall epidemiologic situation as per feral herd infections and zoogenous infections with agents belonging to II pathogenicity group remained relatively safe. Diseases cases weren't group episodes and were sporadic. $68.2 \%$ cases in morbidity structure over 2002014 belonged to HFRS; epidemic onsets for this disease are characteristic in subtropical areas of Krasnodar Kray throughout a year which is related to climatic peculiarities and natural reservoirs of Hantavirus. In particular, 
in Sochi over 200-2015 8 cases (40\%) of this infection were registered in autumn; 4 (20\%), in winter; $3(15 \%)$, in spring: and $5(25 \%)$, in summer. Additional dangers were determined by the results of epizootologic research of the Kray territory. For example, in $201339.0 \%$ of samples with HFRS were taken in Adler district of Sochi where most sport and infrastructure objects were located and where participants and guests of mass events lived [8].

Available epidemiologic data and the results of accomplished assessment within population health risk management activities gave the grounds for a decision to take preventive measures against HFRS before the Olympics-2014. Additional activities on territory development and deratization were organized in Adler district in Sochi. Quarterly planned epizootologic examinations were provided at stationary observation points in forest-park zones; such examinations were also accomplished two times a year (in spring and in autumn) in Hantavirus feral herds. Experts worked out recommendations for medical and preventive organizations in Krasnodar Kray on providing better readiness for possible HFRS infection; training workshops for medical personnel devoted to diagnostics and treatment of feral herd infections and extremely dangerous infections were organized [8].

Due to all the implemented activities we managed to avoid serious epidemiologic complications in terms of HFRS. An only case of this disease was registered in Sochi in August 2014.

When greatest mass events takes place, risks increase substantially and workloads also grow dramatically; therefore, additional labor resource are usually brought from other administrative territories and the RF regions [6]. To reinforce laboratory services during the Olympics-2014 a specialized anti-epidemic team (SAET) from Rospotrebnadzor "Stavropol Antiplague Institute" worked in Sochi [5, 10]. SAET indicative laboratory functioned in Sochi during mass events which took place in spring, summer, and autumn in 2014-2016.

One of the tasks which were assigned for the team was to prepare for diagnostics of maximum list of infectious diseases. As per results of world epidemiologic situation analysis a list of agents inducing 82 nosologic infectious forms was drawn. Polymerase chain reaction (PCR) was determined as a basic specific indication technique for most pathogens of bacterial and viral nature. Volume of necessary stock of PCR test-systems required for analysis as per epidemic parameters was calculated with the use of a technique designed for mass events and based on determining epidemic complications risk in relation to each separate nosologic form. Assessment criteria in form of questions (totally 16) were formulated allowing for providing multi-factor analysis principles use.

Specific weight of various factors in the overall questions structure was as follows:

- "internal" epidemiologic risks as per an infection were 0.4375 ;

- "external" epidemiologic risks as per an infection were 0.125 ;

- risk for infection spread in the region was 0.125 ;

- risk for biological terrorism with the use of infectious agent was 0.0625 ;

- retrospect data on epidemic complications as per an infection during mass events were 0.0625 ;

- peculiarities of laboratory diagnostics organization during a planned mass event were 0.1875 .

So, overall questions structure included not only epidemiologic risks but also algorithms of materials introduction into research; in other words, it enabled determining whether SAET was a main or a support base in diagnostics of a corresponding nosologic form. And a question list was flexible allowing changes in specific weights of various factors depending on a specific event peculiarities.

All infections were divided into three groups with the use of the developed technique according to degree of preparation each infection required: minimum preparation (or basic 
one), increased preparation, and maximum preparation. After this division a possible volume of laboratory research during a mass event was set for each infections group and PCR test-systems stocks were accumulated on the basis of research volumes calculations. Stocks accumulation was accomplished as per 1:2-1:4 research ratio in relation to basic one for additional specific indication technique (an immune analysis technique).

As a results, equipping of SAET with diagnostic drugs during preparation to mass events was based on systemic principle. Riskoriented approach application together with multi-factor analysis enabled precise calculations of possible maximum needs of the team in case of each separate infectious nosologic form. The number of performed research on epidemiologic reasons didn't exceed forecast figures. A stock of diagnostic test-systems was preserved for detection of absolutely all pathogens and it proves that SAET was sufficiently equipped with all necessary materials.

To facilitate managerial decisions in the sphere of sanitary-epidemiologic welfare of population during the Olympics-2014 experts of Rospotrebnadzor "Stavropol Scientific Research Antiplague Institute" created an innovative product, namely, a computer program based on geographical information system (GIS) platform [4]. This instrument made it possible to carry out a live time-spatial situation analysis. GIS-program included several layers: data on infectious diseases among population in the region, sanitary-hygienic situation at epidemiologically significant objects (ESO), information on workloads of laboratory bases, results of laboratory examinations performed on specialized occupational groups (workers who are included into such groups are to have regular medical check-ups; the list is approved by the RF Government) and on hot water supply systems in terms of Legionella occurrence, as well as other essential information. To implement the system into everyday work, an information interaction algorithm was created and later on implemented. Data from Rospotrebnadzor regional operative office in Krasnodar Kray were sent to a SAET on-duty worker: they were then processed and fed into the system. Information was available for specialists who participated in providing sanitary and epidemiologic safety of the event. All the data could be viewed and analyzed through any stationary or mobile device provided it had access to the Internet at a speed not less than 1 Mbit per minute $[1,4,8]$.

Within the frameworks of risk-oriented approach application 629 epidemiologically significant objects in Sochi mapped in the GIS were preliminary ranked as per results of surveillance activities; they were divided into having "low", "average", "high", and "too high" risks for population. Disciplinary actions or additional inspections were assigned depending on the objects' potential danger. If certain preventive activities were accomplished then according to sanitary-hygienic situation assessment ESO could be moved into other categories with lower risk. All the necessary information was real-time presented in the GIS.

To control epidemiologic situation in the region, new analysis criteria were first used: "dynamic epidemiologic threshold", or a number of sick people on a certain territory over time; "epidemiologic spot", or spatial location of a diseases cases over an analyzed period of time $[1,4,8]$.

"Dynamic epidemiologic threshold" criterion was adapted exactly for short-term and relatively short-term events. It helps to assess situation development as most up-to-date information is used when calculating it. It makes it possible to react most promptly in case epidemiologic situation deteriorates and it is truly essential during a mass event. During the Olympics-2014 "dynamic epidemiologic threshold" was calculated daily for measles, chickenpox, acute enteric infections and acute respiratory viral infections of various etiology. When it was exceeded and a possibility of an epidemiologic spot formation as per one or several nosologies occurred, a warning automatically appeared in the GIS.

During the Olympics-2014 several episodes of epidemiologic spots formation were registered; such epidemiologic spots meant 
that diseases cases occurred in close proximity to each other and away from other diseases cases, there was one preliminary diagnosis out within 1-3 days time. For example, due to prompt reaction, specialists managed to prevent spread of measles.

Conclusions. Thus, new scientifically grounded approaches oriented at population health risk analysis concepts were worked out and later implemented during planning, organizing and accomplishing activities within epidemiologic surveillance system during preparation to and mass events themselves in Sochi.

A set of preventive activities in relation to feral herd infections and zoogenous infections endemic for Sochi territory and Krasnodar Kray as a whole, was planned allowing for accomplished assessment of epidemiologic complications risks. For the first time, a technique aimed at determining SAET needs in diagnostic preparations during mass events is introduced. Equipping SAET with test-systems for specific indication on the basis of performed calculations enabled to provide necessary readiness of laboratories, on the one hand, and to avoid excessive expenditure, on the other hand. Application of the GIS in everyday work during the Olympics-2014 made it possible to get a number of advantages, including more simple and faster information exchange in intra- and interdepartmental interaction.

Risk-oriented organization of certain activities in the system of providing antiepidemic safety during mass international events on the RF territory was quite new experience for us. Its results make us optimistic about future prospects of wider implementation of the described approaches and other similar ones based on health risk analysis, into theory and practice of epidemiological surveillance.

Implementation of the created technique for assessing epidemiologic complications risks seems to be vital exactly during preparation for mass events which have fixed time limits. Its various modifications were applied in developing managerial decisions on preventing feral herd infections and zoogenous extremely dangerous infections as well as in determining volumes of equipping SAET with diagnostic test-systems. An issue of whether it is advisable to develop the technique further by introducing step-up and step-down coefficients for specific questions and danger factors representing their significance in the overall structure, still requires scientific justification.

\section{References}

1. Onishchenko G.G., Popova A.Yu., Kuz'kin B.P., Bragina I.V., Ezhlova E.B., Demina Yu.V. [et al.]. XXII Olimpiiskie zimnie igry i XI Paralimpiiskie zimnie igry 2014 goda v g. Sochi. Obespechenie sanitarno-epidemiologicheskogo blagopoluchiya [XXII Winter Olympic Games and XI Winter Para-Olympic Games-2014 in Sochi. Sanitary and epidemiologic welfare provision]. In: akad. RAN G.G. Onishchenko, prof. A.N. Kulichenko eds. Tver', OOO «Izdatel'stvo «Triada» Publ., 2015, 576 p. (in Russian).

2. Onishchenko G.G., Popova A.Yu., Smolenskii V.Yu., Maletskaya O.V., Taran T.V., Dubyanskii V.M., Semenko O.V., Agapitov D.S., Grizhebovskii G.M., Manin E.A., Klindukhov V.P., Orobei V.G., Antonenko A.D. Analiz zarubezhnogo opyta obespecheniya biologicheskoi bezopasnosti pri provedenii Olimpiiskikh igr [Analysis of foreign experience of maintenance of biological safety of the Olympic games]. Zhurnal mikrobiologii, epidemiologii i immunobiologii, 2015, no. 2, pp. 105-109 (in Russian).

3. Onishchenko G.G., Zaitseva N.V., May I.V., Shur P.Z., Popova A.Yu., Alekseev V.B. [et al]. Analiz riska zdorov'yu $\mathrm{v}$ strategii gosudarstvennogo sotsial'no-ekonomicheskogo razvitiya: monografiya [Health risk analysis in the strategy of state social and economic development: monograph]. In: G.G. Onishchenko, N.V. Zaitseva eds. Moscow, Perm', Izd-vo Permskogo natsional'nogo issledovatel'skogo politekhnicheskogo universiteta Publ., 2014,783 p. (in Russian).

4. Popova A.Yu., Kuz'kin B.P., Demina Yu.V., Dubyanskii V.M., Kulichenko A.N., Maletskaya 
O.V. [et al.]. Ispol'zovanie sovremennykh informatsionnykh tekhnologii $\mathrm{v}$ praktike sanitarnoepidemiologicheskogo nadzora v period provedeniya XXII Olimpiiskikh zimnikh igr i XI Paralimpiiskikh zimnikh igr $\mathrm{v}$ g. Sochi [Using modern information technology in the practice of the sanitaryepidemiological surveillance during the xxii Olympic winter games and xi paralympic winter games in Sochi]. Zhurnal mikrobiologii, epidemiologii i immunobiologii, 2015, no. 2, pp. 113-118 (in Russian).

5. Onishchenko G.G., Kuz'kin B.P., Demina Yu.V., Kulichenko A.N., Maletskaya O.V., Efremenko D.V. [et al.]. Obespechenie gotovnosti i organizatsiya raboty SPEB FKUZ «Stavropol'skii protivochumnyi institut» Rospotrebnadzora v period provedeniya XXII Olimpiiskikh zimnikh igr i XI Paralimpiiskikh zimnikh igr v Sochi [Provision of the Preparedness and Management of Work of the Specialized Anti-Epidemic Team at the Premises of the Rospotrebnadzor Stavropol Anti-Plague Institute during the XXII Olympic and XI Paralympic Winter Games in Sochi]. Problemy osobo opasnykh infektsii, 2015, no. 1, pp. 58-62 (in Russian).

6. Kulichenko A.N., Efremenko D.V., Kuznetsova I.V., Zaitseva O.A. Obespechenie gotovnosti spetsializirovannykh protivoepidemicheskikh brigad $\mathrm{k}$ rabote pri provedenii massovykh meropriyatii [Operation preparedness of specialized anti-epidemic brigades during mass events]. Zhurnal epidemiologii, mikrobiologii i immunobiologii, 2014, no. 1, pp. 76-80 (in Russian).

7. Onishchenko G.G., Kulichenko A.N., Zaitseva O.A., Efremenko D.V. Opyt stranorganizatorov Olimpiad po obespecheniyu zashchity ot biologicheskoi ugrozy [Experience of Olympic host-countries in procuring protection from a biological threat]. Zhurnal mikrobiologii, epidemiologii $i$ immunobiologii, 2014, no. 1, pp. 70-75 (in Russian).

8. Orobei V.G. Mery profilaktiki chrezvychainykh situatsii sanitarno-epidemiologicheskogo kharaktera pri provedenii XXII Olimpiiskikh zimnikh igr i XI Paralimpiiskikh zimnikh igr v g. Sochi: avtoref. dis. ... kand. med. Nauk [Measures at preventing sanitary and epidemiologic contingencies during XXII Winter Olympic Games and XI Winter Para-Olympic Games-2014 in Sochi: abstract of a thesis. ... candidate of medical science]. Stavropol', 2016, 22 p. (in Russian).

9. Onishchenko G.G., Novikov S.M., Rakhmanin Yu.A., Avaliani S.L., Bushtueva K.A. Osnovy otsenki riska dlya zdorov'ya naseleniya pri vozdeistvii khimicheskikh veshchestv, zagryaznyayushchikh okruzhayushchuyu sredu: monografiya [Basics of population health risk assessment under exposure to chemicals polluting environment: monograph]. In: Yu.A. Rakhmanin, G.G. Onishchenko eds. Moscow, NII ECh and GOS, 2002, 408 p. (in Russian).

10. Kuz'kin B.P., Kulichenko A.N., Maletskaya O.V., Efremenko D.V., Manin E.A., Kotenev E.S. [et al.]. Rezul'taty raboty SPEB FKUZ «Stavropol'skii protivochumnyi institut» Rospotrebnadzora v period provedeniya XXII Olimpiiskikh zimnikh igr i XI Paralimpiiskikh zimnikh igr v Sochi [Performance of the SAET of the Stavropol Anti-Plague Institute of the Rospotrebnadzor during the XXII Olympic and XI Paralympic Winter Games in Sochi]. Problemy osobo opasnykh infektsii, 2015, no. 2, pp. 17-21 (in Russian).

11. Communicable diseases alert and response for mass gatherings: key consideration. Geneva, WHO, 2009, $130 \mathrm{p}$.

12. Abubakar I., Gautret P., Brunette G.W., Blumberg L., Johnson D., Poumerol G., Memish Z.A., Barbeschi M., Khan A.S. Global perspectives for prevention of infectious diseases associated with mass gatherings. The Lancet Infectious Diseases, 2012, no. 12, pp. 66-74.

13. Moran-Gilad J., Chand M., Brown C., Shetty N. Microbiological aspects of public health planning and preparedness for the 2012 Olympic Games. Epidemiol Infect, 2012, vol. 140, no. 12, pp. 2142-2151.

14. Brownstein J.S., Freifeld C.C., Reis B.Y., Mandl K.D. Surveillance Sans Frontières: Internet-based emerging infectious disease intelligence and the Health Map project. PLoS Med, 2008, no. 5 , pp. 151.

15. Wilson K., Brownstein J.S. Early detection of disease outbreaks using the Internet. CMAJ, 2009, vol. 180, pp. 829-831. 
Efremenko D.V., Kuznetsova I.V., Orobey V.G., Efremenko A.A., Dubyanskiy V.M., Manin E.A., Prislegina D.A., Semenko O.V. Risk-oriented approach application at planning and orginizing antiepidemic provision of mass events. Health Risk Analysis, 2017, no. 1, pp. 4-12. DOI: 10.21668/health.risk/2017.1.01.eng

Received: 28.12.2016

Accepted: 18.02.2017

Published: 30.03.2017 